\title{
Iodine Agronomic Biofortification of Cabbage (Brassica oleracea var. capitata) and Cowpea (Vigna unguiculata L.) Is Effective under Farmer Field Conditions
}

\author{
Joe Ojok ${ }^{1}$, Peter Omara ${ }^{2, *(\mathbb{D})}$, Emmanuel Opolot ${ }^{2,3}{ }^{\mathbb{D}}$, Walter Odongo ${ }^{4}$, Solomon Olum ${ }^{1,5}{ }^{(}$, \\ Du Laing Gijs ${ }^{6}$, Xavier Gellynck ${ }^{5}$, Hans De Steur ${ }^{5}$ and Duncan Ongeng ${ }^{1}$ \\ 1 Department of Food Science and Postharvest Technology, Gulu University, Gulu P.O. Box 166, Uganda; \\ ojokjoe@gmail.com (J.O.); solomonolum@gmail.com (S.O.); duncanongeng@hotmail.com (D.O.) \\ 2 Department of Agronomy, Gulu University, Gulu P.O. Box 166, Uganda; oplote@yahoo.com \\ 3 Department of Agricultural Production, Makerere University, Kampala P.O. Box 7062, Uganda \\ 4 Department of Rural Development and Agribusiness, Gulu University, Gulu P.O. Box 166, Uganda; \\ odongo_walter@yahoo.co.uk \\ 5 Department of Agricultural Economics, Ghent University, Coupure Links 653, 9000 Ghent, Belgium; \\ xavier.gellynck@ugent.be (X.G.); Hans.DeSteur@ugent.be (H.D.S.) \\ 6 Department of Green Chemistry and Technology, Ghent University, Coupure Links 653, 9000 Ghent, \\ Belgium; Gijs.DuLaing@ugent.be \\ * Correspondence: peter.omara@okstate.edu; Tel.: +1-405-762-8292
}

Received: 22 September 2019; Accepted: 21 November 2019; Published: 23 November 2019

\begin{abstract}
Iodine (I) is an essential micronutrient, which plays a critical role in human metabolism. However, its concentration is known to be low in most soils, making it deficient in crops. With most I agronomic biofortification studies conducted under controlled environments, limited information currently exists on this approach of enriching I deficient crops under farmer field conditions. Two-year field experiments were conducted in 2017 and 2018 to examine efficacy of cowpea and cabbage in the uptake of foliar applied potassium iodide (KI) and potassium iodate $\left(\mathrm{KIO}_{3}\right)$, each with $0,5,10$, and $15 \mathrm{~kg} \mathrm{I} \mathrm{ha}^{-1}$ under farmer field conditions. Results indicate that $\mathrm{KI}$ was $34 \%$ more efficient than $\mathrm{KIO}_{3}$. Iodine concentration increased with application rate. In cabbage, the lowest I concentration $(8.2 \mathrm{mg}$ $\mathrm{kg}^{-1}$ ) was registered at $5 \mathrm{~kg} \mathrm{I} \mathrm{ha}^{-1}$ with $\mathrm{KIO}_{3}$ while the highest was $109.1 \mathrm{mg} \mathrm{kg}^{-1}$ at $15 \mathrm{~kg} \mathrm{I} \mathrm{ha}^{-1}$ with KI. Cowpea registered the lowest I concentration of $531.5 \mathrm{mg} \mathrm{kg}^{-1}$ at $5 \mathrm{~kg} \mathrm{I} \mathrm{ha}^{-1}$ with $\mathrm{KIO}_{3}$ while the highest (5854.2 $\mathrm{mg} \mathrm{kg}^{-1}$ ) was registered at $15 \mathrm{~kg} \mathrm{I} \mathrm{ha}^{-1}$ with KI. Therefore, cowpea and cabbage can be effectively biofortified through foliar application of both $\mathrm{KI}$ and $\mathrm{KIO}_{3}$ under farmer field conditions.
\end{abstract}

Keywords: agronomic biofortification; leafy vegetables; iodine foliar application; field experiment

\section{Introduction}

Iodine (I) is an essential micronutrient, which plays a critical role in the human metabolism. It is a component of thyroid hormones thyroxine (T3) and tri-iodothyrosine (T4) [1]. These hormones are involved in physiological body processes such as reproductive functions, growth, development, and metabolism [2]. Inadequate uptake of I in the diet, sometimes colloquially referred to as "hidden hunger", results in physiological disorders and biological function abnormalities called iodine deficiency disorders (IDD) such as enlarged thyroid gland (goiter) and cretinism [3,4]. Globally, 2 billion people are estimated to be deficient of I. In Africa, 332 million people are reported to have inadequate I 
intake [5]. The food and nutrition technical assistance (FANTA II) [6] study reported the total goiter rate (TGR) among school going children of age 6-12 years in Uganda at 31\% with recent stakeholder study revealing that goiter cases are frequently seen in the community [7]. This is substantially higher than the goiter rate of $5 \%$ threshold reported by Bimenya et al. [8] to consider I deficiency as a public health problem.

Generally, the high prevalence of IDD has been attributed to the limited access to I-rich foods such as sea foods as well as inadequate amount of I in edible plant parts [9]. In an effort to increase the intake of I, universal salt iodization (USI) has been widely implemented. However, despite its implementation for decades now, I deficiency still remains a major threat to the health and development of populations in Sub-Saharan Africa [10]. Additionally, salt iodization has been associated with an increase in the occurrence of cardiovascular diseases as a result of excessive salt consumption [11].

Following these limitations, the World Health Organization [12] recommended reduction in salt content in the diet as well as searching for alternative approaches to increase the I content in the diet. One such novel strategy is agronomic biofortification, a technique of supplying micronutrients through soils or plant leaves to increase their contents in edible plant parts [13]. Agronomic biofortification of staple crops is considered to be a cost-effective and sustainable approach to address IDD in resource constrained settings [14].

A number of agronomic biofortification studies that focused on other micronutrients such as zinc and iron have yielded promising results using horticultural crops, such as tomato, spinach, and fruit $[15,16]$. However, several issues concerning agronomic I biofortification remain to be addressed. For instance, limited studies exist on the efficiency of I retention in crops, the effect of application rate, and the effect of form of application are yet to be conclusively studied. Additionally, most of the available studies have been done in pots and hydroponic culture systems in laboratory settings [17,18]. While past studies give initial suggestions of the effectiveness of agronomic biofortification, the use of controlled environments does not provide reliable estimates of how such applications would behave under open field conditions [18], hence limiting the applicability of laboratory findings. Consequently, there is a need to move beyond the controlled environment to field trials. To this effect, few field trials have been conducted to assess the efficiency of different plants to absorb and accumulate exogenous I [19-21]. If applied through the soil, the low mobility as well as physicochemical properties of soil can limit plant uptake efficiency of I. In addition, soil application can also affect translocation efficiency. For instance, Weng [21] observed a decreasing trend of retention of soil applied I from root, leaf, to fruit. On the other hand, biofortification of I through foliar application is known to be more effective than soil application. Lawson et al. [20] reported higher efficiency of foliar applied I compared to soil application in butterhead lettuce. However, the authors noted that the effectiveness of foliar spray can be increased by use of surfactant in the spray solution. This study, therefore, used farmer field-based trials for evaluating the efficiency of cabbage (Brassica oleracea var. capitata) and cowpea (Vigna unguiculata L.) crops, both commonly consumed as leafy vegetables in Northern Uganda, to take up and accumulate foliar applied I. Specifically, this study aimed to (1) evaluate the effect of I form on absorption of I in edible parts of cabbage and cowpea leafy vegetable crops; and (2) determine the effect of I application rate on I content in edible parts of cabbage and cowpea vegetable crops.

\section{Materials and Methods}

\subsection{Study Area and Experimental Set Up}

Field trials were conducted at Gulu $\left(02^{\circ} 46.742^{\prime} \mathrm{N}, 032^{\circ} 20.097^{\prime} \mathrm{E}\right)$ and Lira $\left(02^{\circ} 18.075^{\prime} \mathrm{N}\right.$, $032^{\circ} 56.690^{\prime}$ E) in Northern Uganda, between September 2017 and January 2018, and from March to August 2018. Total monthly rainfall and average air temperature for both locations and planting seasons were computed (Figure 1). A randomized complete block design was used with 8 treatments and 3 replications for each of the Cabbage and Cowpea crops. A factorial arrangement consisting of 
two I forms i.e., potassium iodide (KI) and potassium iodate $\left(\mathrm{KIO}_{3}\right)$, and four application rates $(0,5,10$, and $15 \mathrm{~kg} \mathrm{I} \mathrm{ha}^{-1}$ ) was used in the experiments.

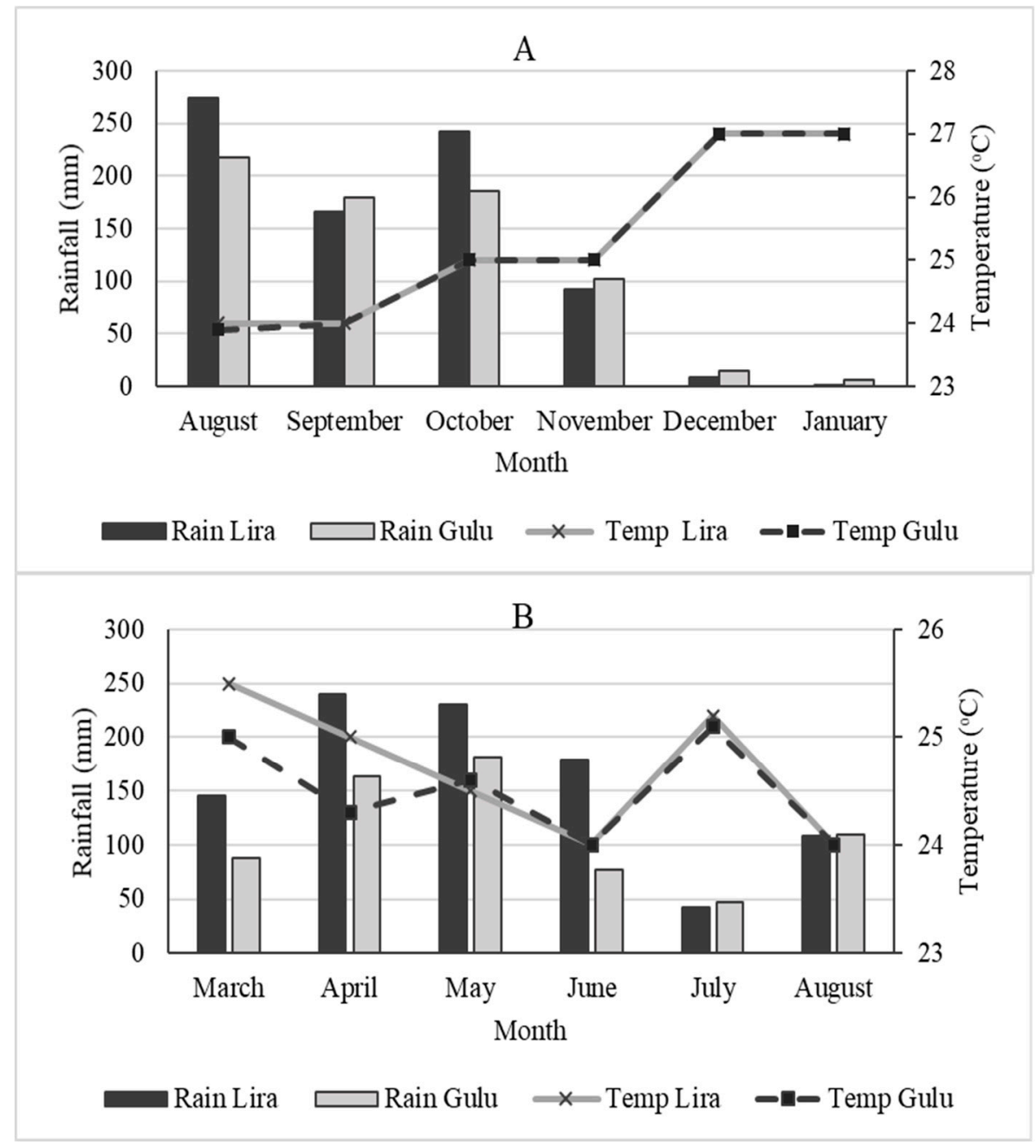

Figure 1. Total monthly rainfall and average air temperature for Lira and Gulu experimental locations;

(A) second planting season 2017 and (B) First planting season 2018.

Cabbage and Cowpea seeds were disinfected by soaking in $1 \%$ potassium permanganate $\left(\mathrm{KMnO}_{4}\right)$ solution for $20 \mathrm{~min}$ and thoroughly rinsed with clean water before planting. Baraka F1 hybrid Cabbage seeds were sown into a nursery bed at a row spacing of $15 \mathrm{~cm}$ by continuous and later thinned to $15 \times 5 \mathrm{~cm}$. After four weeks, seedlings with 5-6 leaves were transplanted at $45 \times 60 \mathrm{~cm}$ into $7 \mathrm{~m}^{2}$ main experimental plots. Cowpea seeds were planted directly in the experimental plots at $30 \times 20 \mathrm{~cm}$ on $7 \mathrm{~m}^{2}$ plots.

\subsection{Initial Soil Conditions}

Prior to implementing the treatment structure, soil samples were taken at $0-15 \mathrm{~cm}$ depth and analyzed for organic matter $(\mathrm{OM})$, soil $\mathrm{pH}$, total nitrogen $(\mathrm{TN})$, phosphorus $(\mathrm{P})$, potassium $(\mathrm{K})$, calcium (Ca), magnesium (Mg), I, and soil texture at the National Agricultural Research Laboratories (NARL), Kawanda (Uganda) (Table 1). The air-dried soil samples were pounded, sieved through $2 \mathrm{~mm}$ to remove any debris, then subjected to physical and chemical analysis following standard methods described by Okalebo et al. [22] Soil $\mathrm{pH}$ was measured in a soil water solution ratio of $1: 2.5$, organic matter was measured using potassium dichromate wet acid oxidation method, $\mathrm{N}$ was determined by Kjeldhal digestion, extractable P was estimated following Bray P1 method, while 
exchangeable bases were determined from an ammonium acetate extract using flame photometry $\left(\mathrm{K}^{+}\right)$and atomic absorption spectrophotometry $\left(\mathrm{Ca}^{2+}, \mathrm{Mg}^{2+}\right)$. Soil texture was determined using the Bouyoucos (hydrometer) method. The soil analysis results (Table 1) generally indicated that the soils in the two sites were of average to low soil fertility with low $\mathrm{pH}$ of 4.5 on average. Agricultural lime was applied at a rate of $2.5 \mathrm{tha}^{-1}$ to raise the soil $\mathrm{pH}$ from 4.5 to above the required critical value of 5.2, while NPK (20:5:5) was applied at a rate of $150 \mathrm{~kg} \mathrm{ha}^{-1}$ according to NARL recommendations. Iodine content of the soil was generally lower in Gulu site $\left(1.3 \mathrm{mg} \mathrm{kg}^{-1}\right)$ compared to Lira experimental site $\left(5.6 \mathrm{mg} \mathrm{kg}^{-1}\right)$. Iodine content in the water used in foliar application was not measured. However, the same water source was used for all the experimental plots (treatments) and therefore the effect of the background iodine in water is expected to have a negligible effect on the results.

Table 1. Summary of initial soil conditions at Lira and Gulu experimental locations, 2017.

\begin{tabular}{cccccccccccccc}
\hline Site & $\mathbf{P}$ & $\mathbf{C a}$ & $\begin{array}{c}\mathbf{I} \\
\mathbf{m g} / \mathbf{k g}\end{array}$ & $\mathbf{M g}$ & $\mathbf{K}$ & $\begin{array}{c}\mathrm{TN} \\
\mathbf{g} / \mathbf{k g}\end{array}$ & $\mathbf{p H}$ & $\begin{array}{c}\mathrm{EC} \\
\mathbf{d s} / \mathbf{m}\end{array}$ & $\mathbf{O M}$ & Sand & Clay & Silt & $\begin{array}{c}\text { Textural } \\
\text { Class }\end{array}$ \\
\hline Lira & $\mathbf{1 7}$ & $\mathbf{3 3 3 8}$ & $\mathbf{5 . 6}$ & $\mathbf{4 7 9}$ & $\mathbf{6 2 3}$ & 0.72 & 5.6 & 0.1 & 3.1 & 56 & 19 & 24 & $\begin{array}{c}\text { Sandy } \\
\text { loam }\end{array}$ \\
Gulu & 6 & 1548 & 1.3 & 403 & 98 & 1.09 & 4.5 & 0.1 & 4.7 & 30 & 30 & 39 & Clay loam \\
\hline
\end{tabular}

P, Phosphorus; Ca, Calcium; I, Iodine; Mg, Magnesium; K, Potassium; TN, Total nitrogen; EC, electrical conductivity; OM, Organic matter.

\subsection{Foliar Application of Iodine}

A fixed amount of $\mathrm{KI}$ and $\mathrm{KIO}_{3}$ required for each treatment was weighed using a digital pocket scale BL-100 (American Weigh Scales, Cumming, GA, USA) and dissolved in $500 \mathrm{ml}$ of water to reach a concentration in the spray solution that will provide a dose of I per ha equivalent to a practical application of this amount at a spray volume of $600 \mathrm{~L} \mathrm{ha}^{-1}$ for each treatment [23]. Application was done using automated hand sprayers. The fertilizers $\left(\mathrm{KI}\right.$ and $\left.\mathrm{KIO}_{3}\right)$ were mixed with dimethoate pesticide (Rogo, 30\% EC) at a rate of $1.5 \mathrm{ml} / \mathrm{L}$ of water. Iodine fertilizer applications were split into four doses for each crop, each at $\frac{1}{4}$ of the reported total $\mathrm{KI}_{\text {or }} \mathrm{KIO}_{3}$ dose per ha. Foliar application of cowpeas was started at 21 days after planting (DAP) and the subsequent three applications were carried out at a five-day interval. For cabbages, initial foliar application was carried out at 30 days after transplanting (DAT) and the subsequent three applications were done at a 14-day interval. Sampling of cowpea plants was done five days after the last spraying, while cabbage plants were sampled on average 14 days after the last quarter of foliar application. Spraying was only done on the days when no rainfall was anticipated. Generally, little rainfall was received in November and December of 2017 and January of 2018 at both locations (Figure 1). As a result, experimental plants were irrigated using a watering can.

\subsection{Sampling, Pre-Processing, and Analysis}

Cowpea and cabbage sample plants were collected using $0.5 \mathrm{~m}^{2}$ quadrants. For each plot, a quadrant was thrown into the middle of the plot and plants within the quadrant were uprooted, packed in polythene bags, labeled, and transported to Bioscience analytical laboratory at the National Crop Resources Research Institute (NACRRI), Namulonge for freeze drying and milling. At the laboratory, cowpea and cabbage leaves were plucked and washed thoroughly with running tap water to imitate a common domestic cleaning and spread on the table for excess water to evaporate. Composite leaf samples for each plot were then packed in polythene bags and transferred into freezers maintained between minus $40^{\circ} \mathrm{C}$ to $-80{ }^{\circ} \mathrm{C}$ for preservation prior to lyophilization.

Lyophilization was performed using Labconco (Labconco Corporation, Kansas City, MO, USA) following manufacturers' instructions. Lyophilized samples were pulverized using a motorized seed grinder fitted with a sieve and a collector (Osaw Industrial Products pvt. Ltd, Ambala, India). Pulverized samples were weighed and packed in airtight polythene bags for storage prior to I analysis. Laboratory analysis was conducted using Inductively Coupled Plasma-Mass Spectrometer, ICP-MS 
(PerkinElmer Inc., Waltham, MA, USA) after I extraction using tetra methyl-ammonium hydroxide (TMAH). Chemicals used included: milliQ water, liquid argon (high purity, $99.99 \%), 25 \%(\mathrm{~m} / \mathrm{m})$ tetra methyl-ammonium hydroxide (TMAH, analytical grade, $99.9999 \%$ purity). A commercial stock iodine standard (1000 mg L $\left.\mathrm{m}^{-1}\right)$, internal standard stock solution containing $1000 \pm 3 \mathrm{mg} \mathrm{L}^{-1}$ tellurium (Te) in $2 \%$ $\mathrm{HNO}_{3}$ and $0.2 \% \mathrm{HF}$ were procured from Innochem (Ghent, Belgium). The certified reference material ERM-BD151 (skimmed milk powder) and ERM-BB422 (fish muscle) were analyzed for quality control.

Analysis was done at the laboratory of Analytical Chemistry and Applied Eco chemistry (Ghent University, Belgium). Standard procedure 'NBN EN 15111' for determination of I in foodstuffs by ICP-MS was followed. This consisted of TMAH extraction followed by I determination by ICP-MS. Approximately $0.5 \mathrm{~g}$ of the sample was weighed into a $50 \mathrm{~mL}$ centrifuge tube followed by adding $10 \mathrm{~mL}$ of 5\% TMAH, capped and vortexed for one minute. The mixture was incubated for three hours in a water bath set at $90{ }^{\circ} \mathrm{C}$. The mixture was cooled to room temperature, vortexed for one minute, diluted to a total volume of $50 \mathrm{~mL}$ using milliQ water, weighed, and the final mass was recorded. The solution was centrifuged at $8000 \mathrm{rpm}$ for $10 \mathrm{~min}$ and the supernatant was filtered through a $0.45 \mu \mathrm{m}$ syringe filter to remove large particles that could clog the nebulizer or sample probe during ICP-MS analysis.

A PerkinElmer NexION 350D ICP-MS system (PerkinElmer Inc., Waltham, MA, USA) was used for analysis. The concentration of $\mathrm{I}$ in the samples was determined after external calibration using $0,1,2.5,10,25,50,100$, and $100 \mu \mathrm{gL}^{-1}$ I standards prepared in the same TMAH matrix as the sample extracts. As part of quality control, two reference materials (skimmed milk powder ERM-BD151 and fish muscle ERM-BB422) were analyzed and the percentage recovery of I was determined. Moreover, various levels of iodate (at 5 and $10 \mu \mathrm{g} \mathrm{L}^{-1}$ ) were spiked to the extracts of the plant samples and reference materials and the spike recovery was determined. All results were expressed as iodine concentration $\left(\mathrm{mg} \mathrm{kg}^{-1}\right)$ per dry weight of the sample.

\subsection{Statistical Analysis}

The data obtained were analyzed using the SAS statistical software package version 9.4 [24]. The GLM procedure was used to conduct the analysis of variance (ANOVA) to compare mean concentration of I in cowpea and cabbage samples at various application rates and forms. Means were compared using Tukey's HSD test. In all cases, the level of statistical significance was set at $5 \%(p \leq 0.05)$.

\section{Results}

Iodine fertilizer form, rate, and their interaction were significant while location and replication were not significant for cowpea. Iodine fertilizer form and rate were significant for cabbage while their interaction was not significant (Table 2). Experimental year was significant for both cabbage and cowpea. Consequently, mean I concentrations for both form and rate were obtained across locations and grouped into separate experimental years (2017 and 2018).

Table 2. F-statistics for the effects of location, year, replication, iodine fertilizer rate, form, and their interaction on cowpea and cabbage iodine concentration.

\begin{tabular}{cccccc}
\hline \multirow{2}{*}{ Factor } & \multirow{2}{*}{ D.F $^{+}$} & \multicolumn{2}{c}{ Cowpea } & \multicolumn{2}{c}{ Cabbage } \\
& & $\boldsymbol{F}$ Value & Pr $>\boldsymbol{F}$ & $\boldsymbol{F}$ Value & $\boldsymbol{P r}>\boldsymbol{F}$ \\
\hline Location & 1 & 0.55 & 0.4607 & 13.11 & 0.0005 \\
Replication & 2 & 0.32 & 0.7236 & 0.05 & 0.9507 \\
Year & 1 & 55.26 & $<.0001$ & 14.5 & 0.0003 \\
Iodine Fertilizer Rate & 3 & 81.46 & $<.0001$ & 11.71 & $<.0001$ \\
Iodine Fertilizer Form & 1 & 46.63 & $<.0001$ & 7.02 & 0.0097 \\
Iodine Rate $\times$ Form & 3 & 13.75 & $<.0001$ & 2.6 & 0.0576 \\
\hline
\end{tabular}

${ }^{\dagger}$ D.F, degrees of freedom; Pr., probability 


\subsection{Iodine Fertilizer Form}

Results for experiments conducted in 2017 showed that the concentration of I was significantly higher in plants treated with iodide and iodate compared to the control $(p<0.05)$. The results of the replication of the experiment in 2018 mirrored the trend observed in 2017 (Figures 2 and 3). For cabbages, significant differences between iodide and iodate treated plants were observed in the 2018 experiment but not in 2017, and I concentrations were generally higher for experiments conducted in 2018 than those in 2017 (Figure 2). On the other hand, I concentrations were significantly different between iodide- and iodate-treated cowpeas in both 2017 and 2018 experiments, with higher values obtained in 2017 (Figure 3).

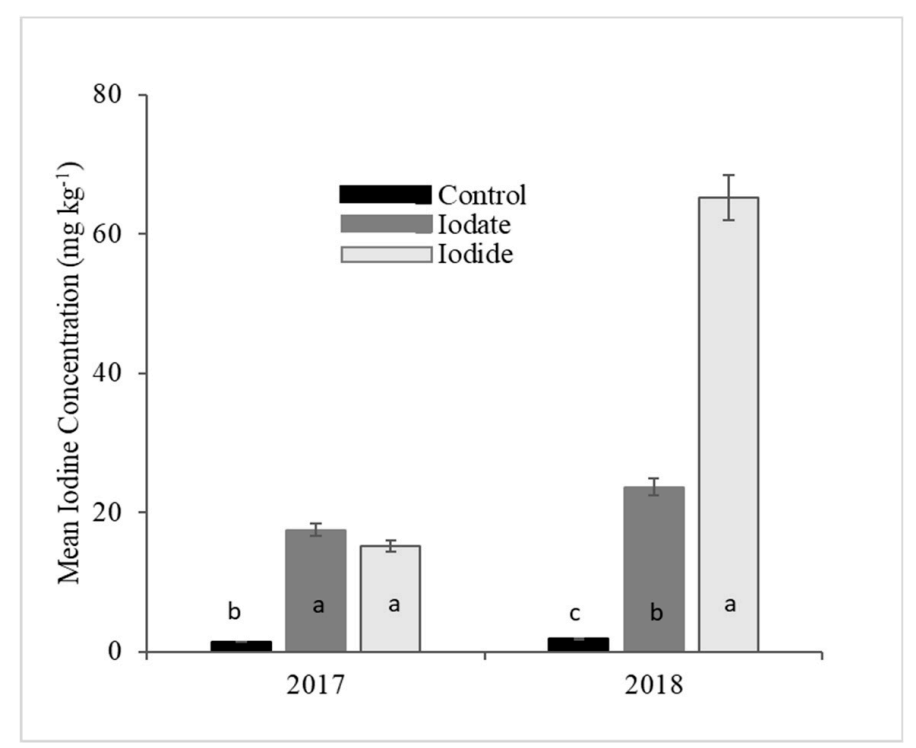

Figure 2. Mean iodine concentration of cabbage for control, iodate-, and iodide-treated plots in 2017 and 2018 (each year, $n=18$ ) for the combined Gulu and Lira sites. Vertical columns within a year with different letters are statistically different at $p<0.05$; Tukey's HSD test.

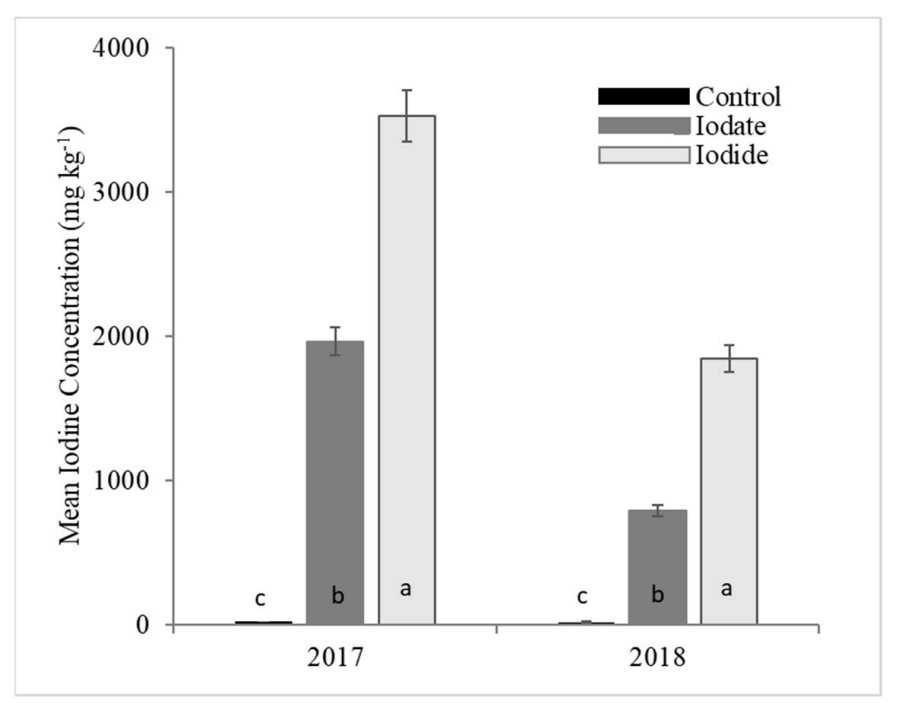

Figure 3. Mean iodine concentration of cowpea for control, iodate-, and iodide-treated plots in 2017 and 2018 (each year, $n=18$ ) for the combined Gulu and Lira sites. Vertical columns within a year with different letters are statistically different at $p<0.05$; Tukey's HSD test. 


\subsection{Iodine Fertilizer Rate}

For cabbage, the 2017 experiments indicated increase in I concentration with increasing application rate, irrespective of the I form applied (Figure 4). On average, the incremental difference between the 5 and 10, and between 10 and $15 \mathrm{~kg} \mathrm{I} \mathrm{ha}^{-1}$ application rate was about $5 \%$ and $13.9 \%$, respectively. In the case of the experiment conducted in 2018, the I concentration in cabbage leaves increased with fertilizer application rate, except for the iodate form, where I concentration in the plant was about $10 \mathrm{mg} \mathrm{kg}^{-1}$ lower for the application rate of $15 \mathrm{~kg} \mathrm{I} \mathrm{ha}^{-1}$ compared to $10 \mathrm{~kg} \mathrm{I} \mathrm{ha}^{-1}$ although they were not significantly different (Figure 4).

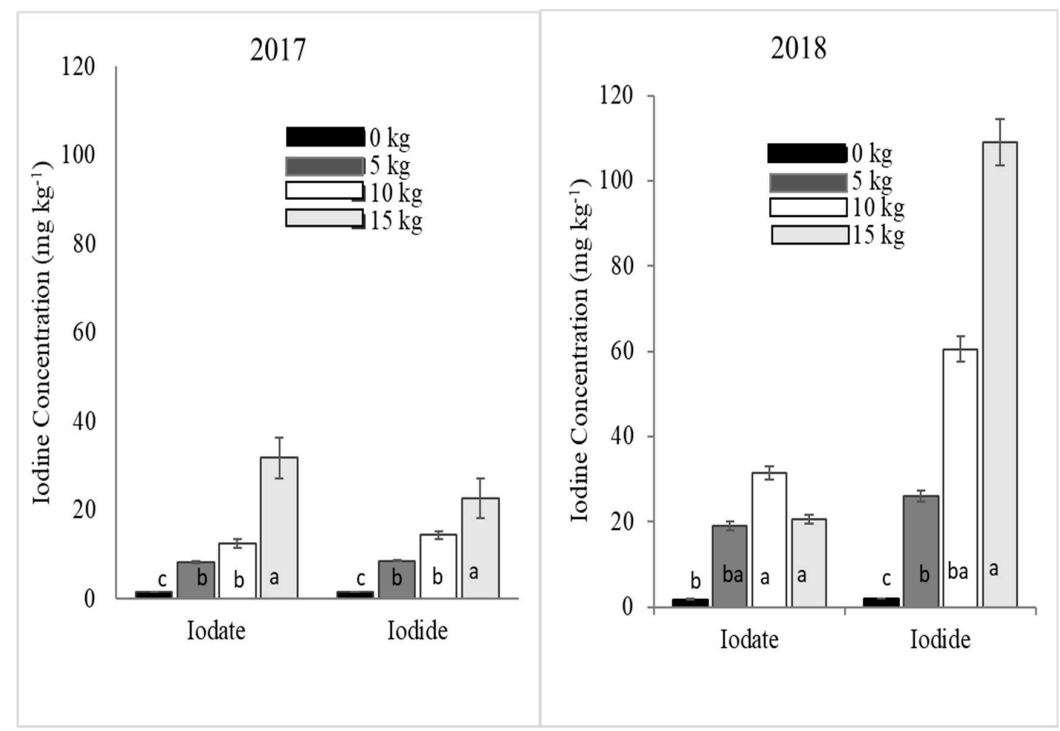

Figure 4. Mean iodine concentration of cabbage for different iodate and iodide fertilizer rates $\left(\mathrm{kg} \mathrm{I} \mathrm{ha}^{-1}\right)$ in 2017 and 2018 (each year, $n=6$ ) for the combined Gulu and Lira sites. Vertical columns within a year with different letters are statistically different at $p<0.05$; Tukey's HSD.

Generally, higher I concentrations in cabbage leaf tissues were observed in the 2018 experiment compared to the 2017 experiment, except for plants treated with iodate fertilizer at $15 \mathrm{~kg} \mathrm{I} \mathrm{ha}^{-1}$, where the opposite was observed (Figure 4). Regardless of the I form, the effect of fertilizer application rate on I concentration in cabbage leaf tissues was registered at application rate of $5 \mathrm{~kg} \mathrm{I} \mathrm{ha}^{-1}$ and significantly increased as the application rate increased to $15 \mathrm{~kg} \mathrm{I} \mathrm{ha}^{-1}$ (Figure 4). However, for the iodide form, the increase was 921.4 and $58.72 \%$ for the same fertilizer application rate shift $(p<0.05)$ compared to the untreated plot. In all cases, the highest I concentration in cabbage leaf tissue was achieved with iodide fertilizer applied at $15 \mathrm{~kg} \mathrm{I} \mathrm{ha}^{-1}$.

Results for I accumulation in cowpea leaf as influenced by application rate for the 2017 and 2018 experiments are presented in Figure 5. For both experiments, accumulation of I in cowpea increased with fertilizer application rate (Figure 5). The increase with application rate was much higher when I was supplied in iodide form than as iodate. Upon iodide application in the 2017 experiment, the concentration of I in cowpea leaf significantly increased by 6137,104 , and $84 \%$ as the application rate increased from 0 to 5,5 to 10 , and 10 to $15 \mathrm{~kg} \mathrm{I} \mathrm{ha}^{-1}$, respectively. In the case of iodate fertilizer (2017), the concentration of I in plant tissue increased by $4968,75.5,23.7 \%$ following fertilizer application rate increases from 0 to 5,5 to 10 and 10 to $15 \mathrm{~kg} \mathrm{I} \mathrm{ha}^{-1}$, respectively. The difference was 357, 1074, and $3.26 \mathrm{mg} \mathrm{kg}^{-1}$ for the fertilizer application rate of 5,10 , and $15 \mathrm{~kg} \mathrm{I} \mathrm{ha}^{-1}$, respectively $(p<0.05)$.

For the iodide fertilizer in the 2018 experiment, the concentration of I in cowpea leaf tissues increased by $4435,79.2$, and $51 \%$ and I was also much higher for iodide than iodate by $475.3,1068.5$, and $1621.3 \mathrm{mg} \mathrm{kg}^{-1}$ for fertilizer application rate of 5,10 , and $15 \mathrm{~kg} \mathrm{I} \mathrm{ha}^{-1}$, respectively $(p<0.05)$. In both seasons, the highest concentration of I in cowpea leaf tissue was achieved with iodide fertilizer applied at $15 \mathrm{~kg} \mathrm{I} \mathrm{ha}^{-1}$ (Figure 5). 


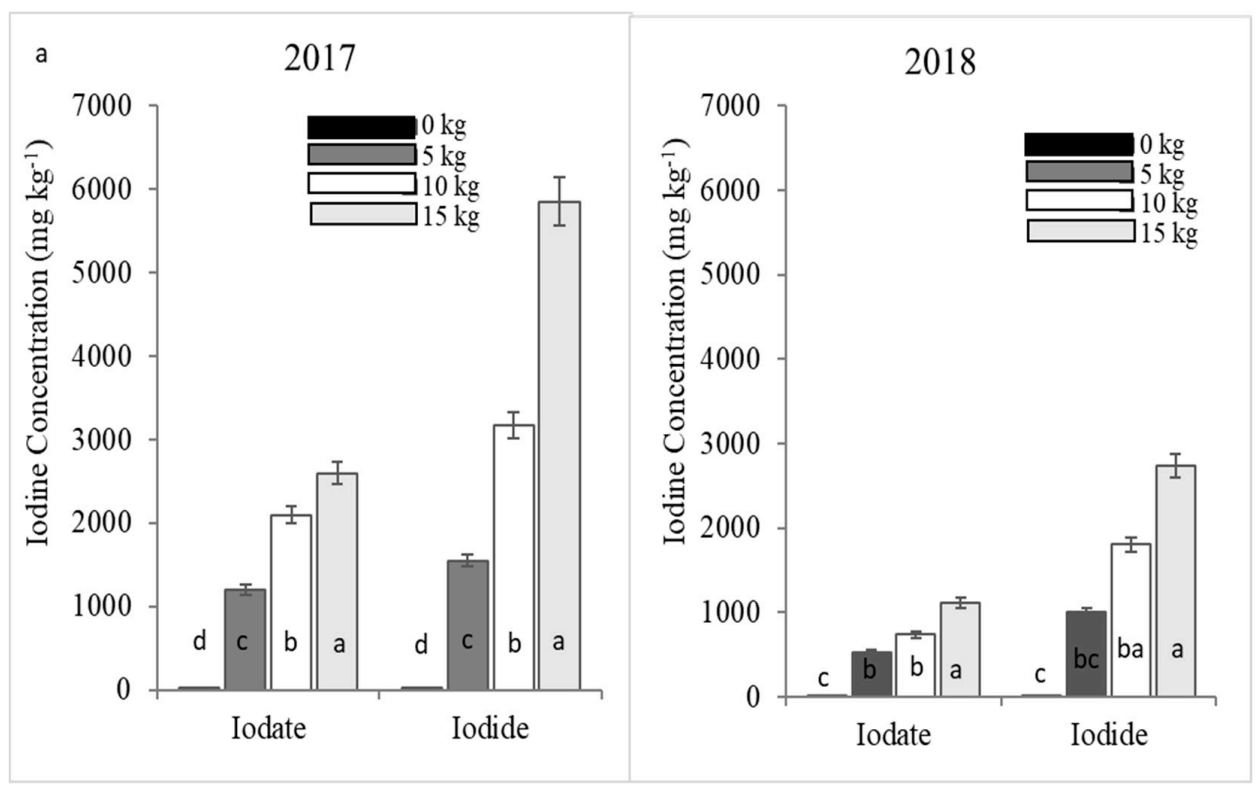

Figure 5. Mean iodine concentration of cowpea for different iodate and iodide fertilizer rates $\left(\mathrm{kg} \mathrm{I} \mathrm{ha}^{-1}\right)$ in 2017 and 2018 (each year, $n=6$ ) for the combined Gulu and Lira sites. Vertical columns within a year with different letters are statistically different at $p<0.05$; Tukey's HSD test.

\subsection{Phytotoxic Effects}

No phytotoxic effects (chlorosis, necrosis, and leaf defoliation) were observed when I was foliar sprayed on cabbage even at higher application rates. On the other hand, both iodate and iodide had phytotoxic effects on cowpea and these effects were more pronounced at higher application rates (Figure 6). At the same application rates, particularly 10 and $15 \mathrm{~kg} \mathrm{I} \mathrm{ha}^{-1}$, foliar application of I in iodide form resulted into more toxic effects (Figure 6: Plates 307 and 308) than when I was supplied in iodate form (Figure 6: Plates 303 and 304)

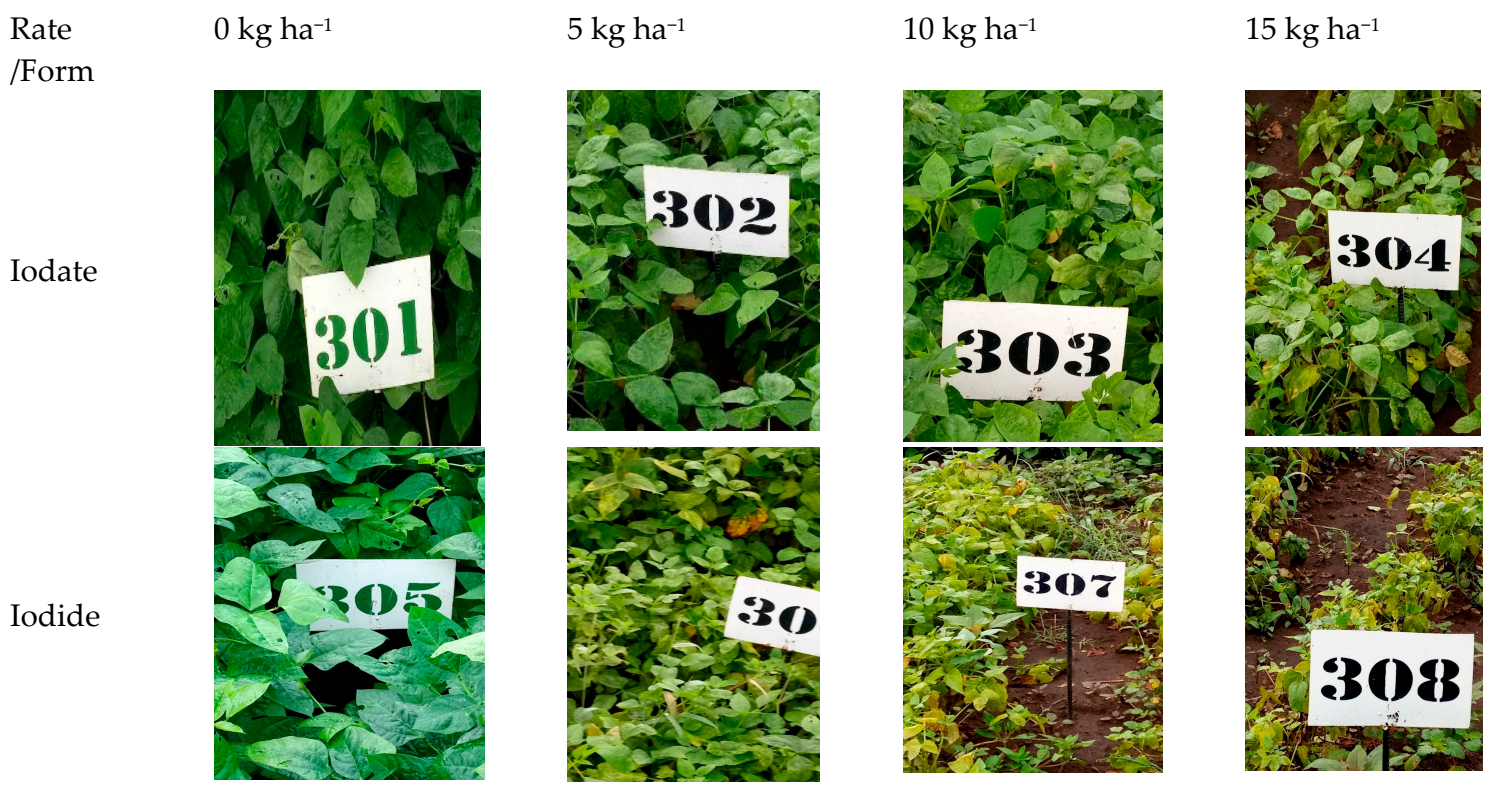

Figure 6. Visual comparison of the effect of application rate on cowpea after spraying with potassium iodate $(302,303$, and 304) and potassium iodide $(306,307$, and 308) in 2018. Note that plates 301 and 305 are from control plots (no foliar application of iodine). 


\section{Discussion}

This study demonstrates significant effects of two I forms on the level of I absorption and retention in cowpea and cabbage leaves. However, the influence of the I form was not consistent for cabbage across the experimental period (2017 and 2018). Overall, the concentration of I in cabbage and cowpea was significantly higher when KI was applied. These results are in line with those obtained in the I biofortification of several other studies $[23,25,26]$. While explaining the difference in the efficacy between KI and KIO3, Lawson et al. [23] stated that the higher efficacy of KI could comparatively be due to its lower point of deliquescence and smaller anion size.

The increase in I concentrations in cabbage leaf tissue when both iodide and iodate were applied was generally low as compared to cowpea. This could be because cabbage has a more closed canopy structure, making complete wetting of the crop difficult compared to cowpea with relatively open canopy structure. Furthermore, the thick waxy layer in cabbage makes foliar application in general challenging due to lower absorption of water by the leaves. As a result, the level of I absorption in cabbage was lower compared to cowpea. The other possible reason for relatively low absorption of I by cabbage could be attributed to the fact that cabbage plants produce enzymes, halogen methyltransferases, which are responsible for the volatilization of the absorbed I from their leaves. Saini et al. [27] reported that I is phytotoxic and its volatilization by aerial plants is seen as a detoxification mechanism. It is also noted that the activity of these enzymes to dissipate I increases with temperature, changes in developmental phases, and under stressful conditions [26]. In the present study, cabbage I concentration was lower in 2017 compared to 2018. Therefore, the high temperature in the last three months of 2017 could have increased the dissipation rate of I in cabbage trials compared to I concentrations of cabbage planted in 2018.

The concentration of I in cowpea samples was generally low in the control treatments. This is an indication of the low availability of plant available soil I in the study area, $1.3 \mathrm{mg} \mathrm{kg}^{-1}$ for Gulu and $5.6 \mathrm{mg} \mathrm{kg}^{-1}$ for Lira experimental location. Similar observations were made by Lawson et al. [23] in Germany where lettuce I concentration in the check plots was generally low and far below the recommended daily I intake. In the treated plots, there were significant differences in the mean concentrations of I, which demonstrated the efficiency of cowpea in uptake of foliar applied I from both carriers. This finding is consistent with the study of Caffagni et al. [25] on tomato fruits and potato tubers. Medrano et al. [28] also reported a positive result when I was applied to soil as $\mathrm{KIO}_{3}$ at doses of $7.5 \mathrm{~kg} \mathrm{ha}^{-1}, 10 \mathrm{mg} \mathrm{kg}^{-1}$ of soil in pots, and leaf spray with $\mathrm{KI}$ at $0.5 \mathrm{~kg} \mathrm{ha}^{-1}$. In the current study, potassium iodide exhibited a higher efficiency than potassium iodate in increasing I concentration in cowpea. This finding corresponds with studies of Zhu et al. [29] and Voogt et al. [30] where I concentrations in plant tissues (spinach and lettuce) were up to five times higher with iodide than with iodate form. Lawson et al. [23] also reported that foliar application of potassium iodide led to a higher concentration of I in lettuce when compared to potassium iodate. Krzepiłko [31], in a similar study, demonstrated that radish and lettuce seedlings grown in the presence of potassium iodide had a higher I content than those grown with potassium iodate. Findings from the current study, however, contradict that of Zhu et al. [29] where at a lower I concentration $(1 \mu \mathrm{M})$ in nutrient solution, I concentration in the leaves of spinach plants treated with iodate exceeded that in leaves treated with iodide. This could be because I was supplied in soil and taken through the roots instead of the leaves. In addition to the difference in the uptake mechanisms between roots and leaves, there is a potential for sorption of I to the soil hence reducing root efficiency.

The efficiency with which plants absorb and retain I seem to be highly dependent on plant species. This is evident from the current study where large differences in the concentration of I were observed between cabbage and cowpea. This confirms earlier assertions made by Weng et al. [32] where the absorption of I in various vegetables was determined by plant type and physiological action of the plant. Similarly, Weng et al. [21] observed that the I uptake was controlled by the I fertilizer application rate as well as the individual plant characteristics. Fernández and Brown [33] summarized that physiological status of the plant and species characteristics such as leaf shape, leaf chemistry, and 
leaf surface characteristics differ from plant to plant and significantly influence absorption of foliar applied fertilizers.

Generally, I concentration in both cowpea and cabbage plants increased with the rate of I fertilizer applied similar to observations by Zhu et al. [29] and Lawson et al. [23] Unlike for cowpea, no detrimental effect of high I application rates was observed for cabbage growth. Many studies reported that once absorbed and accumulated in different plant organs, I is not stable. Medrano et al. [28] reported that some plant species dissipate I as methyl iodide $\left(\mathrm{CH}_{3} \mathrm{I}\right)$ using the enzymes halide ion methyltransferase. This corresponds with earlier findings of Itoh et al. [34] that dissipation of $\mathrm{CH}_{3} \mathrm{I}$ from the sprouting leaves of $R$. sativus, T. aestivum, and O. sativa grown hydroponically increased with increasing concentrations of iodide. Therefore, the concentration of I in the tissues of such plants reduces with time by the activity of the halide enzyme, methyltransferase $[28,35]$. The methyl halide emission potential for plant tissues changes significantly from planting to harvest time [36]. Most importantly is the low uptake efficiency of I by cabbage compounded by thick layering of cabbage leaves can possibly reduce absorption of I initially applied compared to cowpea.

Phytotoxic symptoms observed in cowpea few days after spraying with both potassium iodide and iodate could be due to smaller unit of leaf mass compared to cabbage since similar dosages were applied. Because of relatively smaller unit of leaf mass, the dosage for cowpea seemed high and this was accompanied by the short time interval between the split dose applications. Although the plants could regain after a few days before the next spray, slight defoliation, chlorosis, and necrotic spots on the older leaves remained visible after foliar spray of both I fertilizers at $10 \mathrm{~kg} \mathrm{I} \mathrm{ha}^{-1}$. Immense defoliation and eventual plant death were observed when potassium iodide was applied at $15 \mathrm{~kg} \mathrm{I} \mathrm{ha}^{-1}$. Toxicity of iodide has been attributed to its photo-oxidation to free I in the presence of light, causing chlorophyll destruction [37]. This finding is consistent with observations on butterhead lettuce [23] and spinach $[29,38]$.

\section{Conclusions}

The present study showed that cowpea had higher I concentration than cabbage. Form of I had a significant influence in the concentration of $I$ in the edible tissues of both cowpea and cabbage. In cowpea, iodide was more efficient than iodate. For cabbage, the form of I carrier was inconsistent across experimental years. In 2018, I content in cabbage tissue was $72 \%$ higher when fertilizer was applied as iodide than iodate. However, for the experiment conducted in 2017, there was no significant difference between the two forms. Further investigations using foliar method with more site-years could provide conclusive results on the potential of cabbage to absorb and retain I. Additionally, biofortification experiments that embed biomass measurement in the calculation of total I in crop samples could provide accurate information on the efficiency of I uptake of different crop species. Application rate had a significant influence on the concentration of I in all the crops studied. However, phytotoxic effects were exhibited in cowpea at application rates $\geq 5 \mathrm{~kg} \mathrm{I} \mathrm{ha}^{-1}$. Generally, I concentrations obtained at all application rates in the two crops are more than sufficient to meet the daily adult human required intake of $150 \mu \mathrm{g}$. Specifically, our results indicate that consumption of $100 \mathrm{~g}$ of $\mathrm{KIO}_{3}$ biofortified cabbage at $5 \mathrm{~kg} \mathrm{ha}^{-1}$ would be an equivalent of $820 \mu \mathrm{g}$ while I content of KI biofortified cabbage and both $\mathrm{KI}$ and $\mathrm{KIO}_{3}$ biofortified cowpea at rates $\geq 5 \mathrm{~kg} \mathrm{I} \mathrm{ha}^{-1}$ would be higher than the upper limit of $1100 \mu \mathrm{g}$ [39] per 100g of food consumed. Future studies could determine the optimal application rate less than $5 \mathrm{~kg} \mathrm{ha}^{-1}$ and calculate the contribution to the recommended daily intake of I at each application rate. In addition, future studies could assess the stability of I absorbed when cabbage and cowpea are subjected to various heat treatment processes.

Author Contributions: Conceptualization, W.O., X.G., D.O., and H.D.S.; methodology, P.O. and E.O.; validation, H.D.S.; formal analysis, J.O. and P.O.; investigation, J.O., P.O., and E.O; resources, D.L.G.; writing-original draft preparation, P.O and J.O.; writing-review and editing, P.O., S.O., H.D.S., E.O., and D.L.G.; visualization, S.O.; supervision, W.O; project administration, W.O. and H.D.S.; funding acquisition, W.O., D.O., X.G., and H.D.S. 
Funding: This research was conducted within the framework of the project "Agronomic iodine biofortification to increase iodine intake in Northern Uganda: a stakeholder-based intervention". The project is funded by the Flemish inter University Council (VLIR) TEAM Project 2016 (ZEIN2016PR429).

Acknowledgments: The authors would like to thank Michael Okeny and Awio Tom for their assistance with field work.

Conflicts of Interest: The authors declare no conflict of interest.

\section{References}

1. Zimmermann, M.B. The role of iodine in human growth and development. In Seminars in Cell E Developmental Biology; Academic Press: Cambridge, MA, USA, 2011; Volume 22, pp. 645-652. [CrossRef]

2. Zimmermann, M.B.; Gizak, M.; Abbott, K.; Andersson, M.; Lazarus, J.H. Iodine deficiency in pregnant women in Europe. Lancet Diabetes Endocrinol. 2015, 3, 672-674. [CrossRef]

3. Stewart, C.P.; Dewey, K.G.; Ashorn, P. The undernutrition epidemic: An urgent health priority. Lancet 2010, 375, 282. [CrossRef]

4. Zimmermann, M.B. Iodine deficiency. Endocr. Rev. 2009, 30, 376-408. [CrossRef] [PubMed]

5. Andersson, M.; Karumbunathan, V.; Zimmermann, M.B. Global Iodine Status in 2011 and Trends over the Past Decade. J. Nutr. 2012, 142, 744-750. [CrossRef]

6. FANTA II. The Analysis of the Nutrition Situation in Uganda. Food and Nutrition Technical Assistance II Project; USAID: Washington, DC, USA, 2010.

7. Olum, S.; Gellynck, X.; Okello, C.; Webale, D.; Odongo, W.; Ongeng, D.; De Steur, H. Stakeholders' Perceptions of Agronomic Iodine Biofortification: A SWOT-AHP Analysis in Northern Uganda. Nutrients 2018, 10, 407. [CrossRef]

8. Bimenya, G.S.; Kaviri, D.; Mbona, N.; Byarugaba, W. Monitoring the severity of iodine deficiency disorders in Uganda. Afr. Health Sci. 2012, 2, 63-68.

9. Food and Agriculture Organization (FAO). Uganda Nutrition Profile-Nutrition and Consumer Protection Division; FAO: Rome, Italy, 2010.

10. Saha, S.; Abu, B.A.; Jamshidi-Naeini, Y.; Mukherjee, U.; Miller, M.; Peng, L.L.; Oldewage-Theron, W. Is iodine deficiency still a problem in sub-Saharan Africa? A review. Proc. Nutr. Soc. 2019, 1-13. [CrossRef]

11. Dötsch, M.; Busch, J.; Batenburg, M.; Liem, G.; Tareilus, E.; Mueller, R.; Meijer, G. Strategies to Reduce Sodium Consumption: A Food Industry Perspective. Crit. Rev. Food Sci. 2009, 49, 841-851. [CrossRef]

12. World Health Organization. Reducing Salt Intake in Populations: Report of a WHO Forum and Technical Meeting; World Health Organization: Paris, France, 2007.

13. De Valença, A.W.; Bake, A.; Brouwer, I.D.; Giller, K.E. Agronomic biofortification of crops to fight hidden hunger in sub-Saharan Africa. Glob. Food Secur. 2017, 12, 8-14. [CrossRef]

14. White, P.J.; Broadley, M.R. Biofortification of crops with seven mineral elements often lacking in human diets-Iron, zinc, copper, calcium, magnesium, selenium and iodine. New Phytol. 2009, 182, 49-84. [CrossRef]

15. Landini, M.; Gonzali, S.; Perata, P. Iodine biofortification in tomato. J. Plant Nutr. Soil Sci. 2011, 174, 480-486. [CrossRef]

16. Caffagni, A.; Pecchioni, N.; Meriggi, P.; Bucci, V.; Sabatini, E.; Acciarri, N.; Lombardo, M. Iodine uptake and distribution in horticultural and fruit tree species. Ital. J. Agron. 2012, e32. [CrossRef]

17. Smoleń, S.; Kowalska, I.; Sady, W. Assessment of biofortification with iodine and selenium of lettuce cultivated in the NFT hydroponic system. Sci. Hortic. 2014, 166, 9-16. [CrossRef]

18. Lee, S.; Lee, J. Beneficial bacteria and fungi in hydroponic systems: Types and characteristics of hydroponic food production methods. Sci. Hortic. 2015, 195, 206-215. [CrossRef]

19. Smoleń, S.; Sady, W. Influence of soil application of iodine and sucrose on mineral composition of spinach plants. Acta Sci. Pol. Hortorum Cultus 2011, 10, 3-13.

20. Lawson, P.G.; Daum, D.; Czauderna, R.; Meuser, H.; Härtling, J.W. Soil versus foliar iodine fertilization as a biofortification strategy for field-grown vegetables. Front. Plant Sci. 2015, 6, 450. [CrossRef]

21. Weng, H.; Chunlai, H.; Tianhong, X.; Liting, B.; Huiping, L.; DeWang, L. Iodine biofortification of vegetable plants-An innovative method for iodine supplementation. Chin. Sci. Bull. 2013, 58, 2066-2072. [CrossRef]

22. Okalebo, J.R.; Gathua, W.K.; Woomer, P.L. Laboratory Methods of Soil and Plant Analysis: A Working Manual, 2nd ed.; TSBF-CIAT and SACRED: Nairobi, Kenya, 2002. 
23. Lawson, P.G.; Daum, D.; Czauderna, R.; Vorsatz, C. Factors influencing the efficacy of iodine foliar sprays used for biofortifying butterhead lettuce (Lactuca sativa). J. Plant Nutr. Soil Sci. 2016, 179, 661-669. [CrossRef]

24. SAS Institute Inc. Base SAS 9.4 Procedures Guide: Statistical Procedures, 2nd ed.; SAS Institute Inc.: Cary, NC, USA, 2013.

25. Caffagni, A.; Arru, L.; Meriggi, P.; Milc, J.; Perata, P.; Pecchioni, N. Iodine Fortification Plant Screening Process and Accumulation in Tomato Fruits and Potato Tubers. Commun. Soil Sci. Plant Anal. 2011, 42, 706-718. [CrossRef]

26. Mao, H.; Wang, J.; Wang, Z.; Zan, Y.; Lyons, G.; Zou, C. Using agronomic biofortification to boost zinc, selenium, and iodine concentrations of food crops grown on the loess plateau in China. J. Soil Sci. Plant Nutr. 2014, 14, 459-470. [CrossRef]

27. Saini, H.S.; Attieh, J.M.; Hanson, A.D. Biosynthesis of halomethanes and methanethiol by higher plants via a novel methyltransferase reaction. Plant Cell Environ. 1995, 18, 1027-1033. [CrossRef]

28. Medrano, M.J.; Leija-Martínez, P.; González-Morales, S.; Juárez-Maldonado, A.; Benavides-Mendoza, A. Use of Iodine to Biofortify and Promote Growth and Stress Tolerance in Crops. Front. Plant Sci. 2016, 7, 1146. [CrossRef]

29. Zhu, Y.G.; Huang, Y.Z.; Hu, Y.; Liu, Y.X. Iodine uptake by spinach (Spinacia oleracea L.) plants grown in solution culture: Effects of iodine species and solution concentrations. Environ. Int. 2003, 29, 33-37. [CrossRef]

30. Voogt, W.; Holwerda, H.T.; Khodabaks, R. Biofortification of lettuce (Lactuca sativa L.) with iodine: The effect of iodine form and concentration in the nutrient solution on growth, development and iodine uptake of lettuce grown in water culture. J. Sci. Food Agric. 2010, 90, 906-913. [CrossRef]

31. Krzepiłko, A.; Zych-Wężyk, I.; Molas, J.; Skwaryło-Bednarz, B.; Święciło, A.; Skowrońska, M. The effect of iodine biofortification on selected biological quality parameters of lettuce and radish seedlings. Acta Sci. Pol. Hortorum Cultus 2016, 15, 3-16.

32. Weng, H.X.; Weng, J.K.; Yong, W.B.; Sun, X.W.; Zhong, H. Capacity and degree of iodine absorbed and enriched by vegetable from soil. J. Environ. Sci. China 2003, 15, 107-111.

33. Fernández, V.; Brown, P.H. From plant surface to plant metabolism: The uncertain fate of foliar-applied nutrients. Front. Plant Sci. 2013, 4, 289. [CrossRef]

34. Itoh, N.; Toda, H.; Matsuda, M.; Negishi, T.; Taniguchi, T.; Ohsawa, N. Methyltransferase (HTMT) in methyl halide emissions from agricultural plants: Isolation and characterization of an HTMT-coding gene from Raphanus sativus (daikon radish). BMC Plant Biol. 2009, 9, 116. [CrossRef]

35. Attieh, J.; Kleppinger-Sparace, K.F.; Nunes, C.; Sparace, S.A.; Saini, H.S. Evidence implicating a novel thiol methyltransferase in the detoxification of glucosinolate hydrolysis products in Brassica oleracea L. Plant Cell Environ. 2000, 23, 165-174. [CrossRef]

36. Redeker, K.R.; Manley, S.L.; Walser, M.; Cicerone, R.J. Physiological and biochemical controls over methyl halide emissions from rice plants. Glob. Biogeochem. Cycles 2004, 18, 1. [CrossRef]

37. Mackowiak, C.L.; Grossl, P.R.; Cook, K.L. Iodine toxicity in a plant-solution system with and without humic acid. Plant Soil. 2005, 269, 141-150. [CrossRef]

38. Weng, H.X.; Yan, A.L.; Hong, C.L.; Xie, L.L.; Qin, Y.C.; Cheng, C.Q. Uptake of different species of iodine by water spinach and its effect to growth. Biol. Trace Elem. Res. 2008, 124, 184-194. [CrossRef] [PubMed]

39. Kessler, J. Are there side effects when using supraphysiological levels of iodine in treatment regimens? In Comprehensive Handbook of Iodine. Nutritional, Endocrine and Pathological Aspects; Preedy, V.R., Burrow, G.N., Watson, R.R., Eds.; Academic Press: San Diego, CA, USA, 2009; pp. 107-118.

(C) 2019 by the authors. Licensee MDPI, Basel, Switzerland. This article is an open access article distributed under the terms and conditions of the Creative Commons Attribution (CC BY) license (http://creativecommons.org/licenses/by/4.0/). 